\title{
The Analysis of the Role of Efficiency in the Economic Growth
}

\author{
Xingxing Li \\ 99 ShangDa Road, BaoShan District, ShangHai, China \\ 624291635@qq.com
}

Keywords: Productivity; Efficiency; Institution; Economic growth

\begin{abstract}
Since China's reform and opening up, China's economic growth has attracted the eyes of the world, more and more experts and scholars are interested in China's economic growth, and attempts to reveal the mystery of China's economic growth. This article will driver economic growth into two parts, factor accumulation and productivity, productivity can be decomposed into technology and efficiency. This paper mainly studies the productivity factors affecting economic growth, the emphasis are on efficiency. This article uses the data from 1987 to 2006 since China's reform and opening up, through a certain method of numerical calculation, the efficiency of specific thus separated from productivity. Then, this article selects two system indexes to return to calculate the efficiency, from the angle of institution to analyze the factors that influence efficiency of economic growth.
\end{abstract}

\section{Introduction}

The existed research on China's economic growth mainly focus on the mainstream economic growth theory, the labor, capital and technology factors of production such as contribution to increase economic growth. There are also part of the literature on regional structure in the process of growth and regional development. In this paper, the reason of economic growth is decomposed into two parts, factor accumulation and productivity, productivity and can be decomposed into technology and efficiency of two parts. Elements accumulated refer to the accumulation of capital and labor, it is the content of the mainstream literature research, this article is no longer for analysis. This paper mainly studies the productivity factors affect economic growth, the emphasis is on research efficiency. This article USES the data from 1987 to 2006 since China's reform and opening up, through a certain method of numerical calculation, the efficiency of specific thus separated from productivity. This article selects two system indexes to return, has calculated the efficiency of from the Angle of system to analyze the factors that influence efficiency of economic growth.

\section{The Theoretical Analysis}

The Analysis of Role of Efficiency in the Economic Growth. The reason of economic growth can be decomposed into two parts, factor accumulation and productivity. Productivity refers to the effectiveness of factors into the the output. Productivity can be determined by two factors: the technology and efficiency. The former represents the knowledge of how related factors of production to combine together for production output; The latter measure known technology and production factors to what extent is the practical application. using mathematical language to analysis this kind of relationship, a naturally method is to multiply technology and efficiency, namely

$\mathrm{A}=\mathrm{T} \times \mathrm{E}$

In the formula, $\mathrm{A}$ is productivity index; $\mathrm{T}$ is the technical indicators; $\mathrm{E}$ is efficiency index.

The purpose of this article is to calculate the efficiency in order to return, so not to specific classification efficiency. Only use certain methods to calculate total factor productivity, then select indexes to get technological progress rate, efficiency is derived at last. In this article, the efficiency is used to measure the extent of known technology and production factors is used in practical application.

The Analysis of Role of Institution in the Economic Growth. New institutional economists 
believe that the institution is the root cause of the change of economic growth, the institution has a positive impact on economic growth through the incentive and constraint functions. Effective institution arrangement is the root cause of the economic growth.

In a word, whether the institution can promote the economic growth depends on three aspects: one is institution make compensation and effort associated with the degree of; The second is that they allow the scope of the professional division of labor and trade; 3 it is allowed to identify and seize economic freedom. In this article, the institution is used as the explained variable of the efficiency, institution affect economic growth through efficiency, this article selects the representative indicators of institution and then to return to efficiency.

\section{Data Analysis and Calculation}

The Calculation of Efficiency. By the analysis of the above, can know the reason of economic growth can be decomposed into two parts: element and productivity. Productivity can be decomposed into two parts: technology and efficiency. Expressed in formula is:

$\mathrm{A}=\mathrm{T} * \mathrm{E}$

Type A is productivity index; $\mathrm{T}$ is the technical index; $\mathrm{E}$ is efficiency index. So in order to calculate efficiency, it is necessary to calculate the total factor productivity, and the rate of technological progress. This article selects the data from1987 to 2006, 20 years after China's reform and opening up.

Cobb - Douglas production function $Y=A K^{\partial} L^{\beta}$,With Y, L, K respectively on behalf of output, labor and capital. The parameters A $\partial \beta$, respectively on behalf of total factor productivity, output elasticity of the labor and output elasticity of capital. And we can describe total factor productivity in formula with $A=Y /\left(L^{\alpha} K^{\beta}\right)$.In order to calculate A,we need the data of output quantity, the amount of capital, labor force, and the estimate value of $\partial$ and $\beta$.

The rate of technological progress use (PAT) this index to calculate which means the acceptance number of application for a patent. The efficiency can be calculated according to the formula after technical progress rate and total factor productivity are calculated. The calculation results are shown in table 1. Efficiency of wave pattern is shown in fig. 1.

Table 1 The calculation of efficiency

\begin{tabular}{ccccccc}
\hline Year & GDP & PAT & $\begin{array}{c}\text { Technical } \\
\text { Progress Rate }\end{array}$ & $\begin{array}{c}\text { Total Factor } \\
\text { Productivity }\end{array}$ & $\begin{array}{c}\text { TFP Progress } \\
\text { Rate }\end{array}$ & Efficiency \\
\hline 1987 & 12102.2 & 26077 & - & 33.19714 & - & - \\
1988 & 15101.1 & 34011 & 0.30425 & 34.79252 & 0.04806 & 0.15795 \\
1989 & 17090.3 & 32905 & -0.03252 & 34.42638 & -0.01052 & 0.32361 \\
1990 & 18774.3 & 41469 & 0.26026 & 31.95848 & -0.07169 & -0.27544 \\
1991 & 21895.5 & 50040 & 0.20668 & 33.37005 & 0.04417 & 0.21370 \\
1992 & 27068.3 & 67135 & 0.34163 & 36.28619 & 0.08739 & 0.25580 \\
1993 & 35524.3 & 77276 & 0.15105 & 38.90822 & 0.07226 & 0.47837 \\
1994 & 48459.6 & 77735 & 0.00594 & 41.28849 & 0.06118 & 10.29952 \\
1995 & 61129.8 & 83045 & 0.06831 & 43.0168 & 0.04186 & 0.61279 \\
1996 & 71572.3 & 102735 & 0.23710 & 44.42493 & 0.03273 & 0.13806 \\
1997 & 79429.5 & 114208 & 0.11168 & 45.69557 & 0.02860 & 0.25612 \\
\hline
\end{tabular}




\begin{tabular}{lllllll}
\hline \multicolumn{7}{c}{ Table 1. cont. } \\
1998 & 84883.7 & 121989 & 0.06813 & 46.63721 & 0.02061 & 0.30246 \\
1999 & 90187.7 & 134239 & 0.10042 & 47.27102 & 0.01359 & 0.13534 \\
2000 & 99776.3 & 170682 & 0.27148 & 48.54108 & 0.02687 & 0.09897 \\
2001 & 110270.4 & 203573 & 0.19270 & 49.66428 & 0.02314 & 0.12008 \\
2002 & 121002 & 252631 & 0.24098 & 51.2052 & 0.03103 & 0.12875 \\
2003 & 136564.6 & 308487 & 0.22110 & 52.85601 & 0.03224 & 0.14581 \\
2004 & 160714.4 & 353807 & 0.14691 & 54.19103 & 0.02526 & 0.17193 \\
2005 & 185895.8 & 476264 & 0.34611 & 55.3885 & 0.02210 & 0.06384 \\
2006 & 217656.6 & 573178 & 0.20349 & 56.71448 & 0.02394 & 0.11765 \\
\hline
\end{tabular}

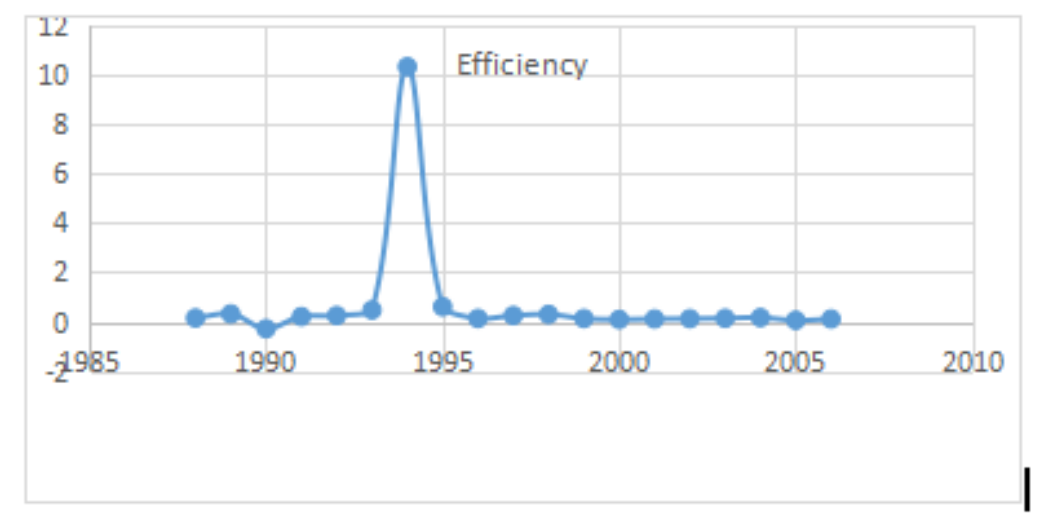

Figure 1. Finite the graph of efficiency

Select Institution Variables. In order to get the quantitative relationship of efficiency and the institution. We should firstly select institution variables. The commonly used institution variables are: ownership reform; Opening to the outside world; Financial deepening reform; The urbanization reform; The institution of science and technology system reform, etc. This article selects the three variables:

$I_{o} \quad$ Opening to the outside world, In proportion of the total amount of FDI to GDP

$I_{T} \quad$ The urbanization reform variable; In proportion of urban population to total population

Two numerical variables are calculated, then we use model to regress..

\section{Model and Regression Analysis}

Model. According to the previous theoretical analysis, empirical research using the regression model is:

$\ln y=\beta_{0}+\beta_{1} \ln x_{1}+\beta_{2} \ln x_{2}+\varepsilon$

In the formula, y represents the efficiency; $x_{1}$ represents $I_{o} ; x_{2}$ represents $I_{T}$.

Regression Results. The regression results with OLS are as Fig.2: 


\begin{tabular}{|c|c|c|c|c|}
\hline \multicolumn{5}{|c|}{$\begin{array}{l}\text { Dependent Variable: } Y \\
\text { Method: Least Squares } \\
\text { Date: 05/15/16 Time: } 19: 33 \\
\text { Sample: } 119 \\
\text { Included observations: } 19\end{array}$} \\
\hline Variable & Coefficient & Std. Error & t-Statistic & Prob. \\
\hline $\mathrm{X} 1$ & 0.839882 & 0.319760 & 2.626604 & 0.0183 \\
\hline $\mathrm{X} 2$ & -4.045797 & 1.140478 & -3.547458 & 0.0027 \\
\hline $\mathrm{C}$ & -2.949526 & 1.354425 & -2.177696 & 0.0447 \\
\hline R-squared & 0.473255 & \multicolumn{2}{|c|}{ Mean dependent var } & -1.455922 \\
\hline Adjusted R-squared & 0.407412 & \multicolumn{2}{|c|}{ S.D. dependent var } & 1.073324 \\
\hline S.E. of regression & 0.826242 & \multicolumn{2}{|c|}{ Akaike info criterion } & 2.600082 \\
\hline Sum squared resid & 10.92282 & \multicolumn{2}{|c|}{ Schwarz criterion } & 2.749204 \\
\hline Log likelihood & & & 2.625319 \\
\hline F-statistic & 7.187608 & \multicolumn{2}{|c|}{ Durbin-Watson stat } & 1.877189 \\
\hline Prob(F-statistic) & 0.005927 & & & \\
\hline
\end{tabular}

Figure 2. Finite Regression results

(1) Fig.2 is regression results of the statistical indicators affecting the efficiency, , respectively analyzes $I_{o}$ the opening to the outside world, $I_{T}$ the urbanization reform;

(2) Fig.2 shows the coefficient of opening to the outside world index is positive, and is significant. That means opening to the outside world has a positive effect on the efficiency, the higher the level of opening to the outside world, the higher the efficiency, the faster economic growth. In the process of opening to the outside world, international trade and foreign direct investment have obvious effect on the growth of technical efficiency, but by comparison, the influence of foreign direct investment is much larger. Investigate its reason, this is due to the important contribution to technical efficiency growth due to a package of resources attached to foreign direct investment(such as management technology and experience, skills and the trick, the integrity of the international distribution network, brand and intangible assets, research and development support, etc. )

(3) Fig.2shows the coefficient of urbanization reform index is negative, and is significant. The urbanization reform do not promote economic growth by promoting economic efficiency. The reasons are as follows :from 1978 to 2012, China's urbanization rate increased from $17.9 \%$ to $17.9 \%$, the annual average increased by $1.02 \%$, not only the advance speed is fast, more importantly, the scale of expansion is unprecedented in human history. Therefore, the success or failure of the urban development is the key to if China can realize its main goals and most of the effort. However, China's expansion of urbanization since reform and opening is in the way of extensive denotative, on the one hand, advance of urbanization focus on speed, push light on quality, the degree of urbanization of agricultural transfer of population is low, urbanization speed and quality does not match. On the other hand, high consumption, high emission, high expansion characteristics, resources allocation efficiency is low, the urbanization push the cost of resources and environment. So, the future of China's urbanization is facing the balance and coordination of environmental protection and economic development quality and efficiency .

\section{Conclusions}

This article uses the data from 1987 to 2006 since China's reform and opening up, through a certain method of numerical calculation, the efficiency of specific thus separated from productivity. This article selects two system indexes to return, has calculated the efficiency of from the Angle of system to analyze the factors that influence efficiency of economic growth.

Regression results show the coefficient of opening to the outside world index is positive, and is significant. That means opening to the outside world has a positive effect on the efficiency, the higher the level of opening to the outside world, the higher the efficiency, the faster economic growth. the coefficient of urbanization reform index is negative, and is significant. The urbanization 
reform do not promote economic growth by promoting economic efficiency.

\section{References}

[1] X.Z. Hu: System innovation function in economic growth way and quantitative research (Ph.D., Huazhong university of science and technology, China 2010), p.28. (In Chinese)

[2] C.L. Li: Research on efficiency in economic growth (Ph.D., Communist Party School, China 2003), p.45. (In Chinese)

[3] Acemoglu, Daron, Simon Johnson, and James A. Robinson, 2004, "Institutions as the Fundamental Cause of Long-Run Growth”, NBER Working Paper 10481.

[4] Mehlum, H. and Moene, K. Institutions and the Resource Curse [J].The economic Journal,2006(01):1-20

[5] Chow, G. and K.Li Accounting for Economic Growth in Taiwan and Mainland China: A comparative Analysis. Journal of Comparative Economics,2002(30):507-530.

[6] Chow, G and K.Li. China's Economic Growth: 1952-2010.Economic Development and Cultural Change, 2002(51):247-256.

[7] D.Domar:,Essays in the Theory of Ecoomic Growth, Oxford University Press, New York, 1957.

[8] Barro, R.J. and Sala Martin, X: Economic Growth, Mc Graw-Hill, New York, 1995

[9] North, D.C. Institutions: Journal of Economic Perspectives, 1991, 31(1):118-125.

[10] Solow, R.M. Technical Change and the Aggregate Production Function [J].The Review of Economics and Statistics, 1957, 39(3). 